E18-2009-27

J. Merešová ${ }^{1}$, M. Florek ${ }^{1}$, K. Holý ${ }^{1}$, M. Ješkovský ${ }^{1}$, I. Sýkora ${ }^{1}$, C. Burda ${ }^{2}$, T. Melicherováa ${ }^{2}$, B. Mankovska ${ }^{3}$, J. Oszlanyi ${ }^{3}$, M. V. Frontasyeva, S. S. Pavlov

\title{
AIR POLLUTION STUDIES IN SLOVAKIA USING AEROSOL FILTERS AND BIOMONITORING TECHNIQUE
}

Submitted to «Ekologia (Bratislava)»

${ }^{1}$ Department of Nuclear Physics and Biophysics, Faculty of Mathematics, Physics and Informatics, Comenius University, Bratislava, Slovakia

${ }^{2}$ Slovak Hydrometeorological Institute, Bratislava, Slovakia

${ }^{3}$ Institute for Landscape Ecology, SAS, Bratislava, Slovakia 
Мерешова Я. и др.
Изучение загрязнений атмосферы Словакии с использованием аэрозольных фильтров
и техники биомониторирования
Инструментальный нейтронный активационный анализ (ИНАА) и атомная абсорбци-
онная спектрометрия (ААС) были использованы для оценки концентраций до 36 хими-
ческих элементов (тяжелые металлы, редкоземельные элементы и актиниды) в атмосфер-
ных аэрозолях. Образцы отбирали на двух площадках в Братиславе. Первая площадка
пробоотбора Лисье удолье - довольно чистое место с незначительным транспортным
движением. Второе место пробоотбора находится вблизи нефтеперерабатывающего за-
вода СЛОВНАФТ. Исследовали воздействие металлургической промышленности в Вели-
кой Иде и вблизи тепловой электростанции в г. Приевидза. В это исследование была
включена и наиболее загрязненная прощада пробоотбора вблизи открытой добычи угля
и тепловой электростанции в Тушимице (Чешская Республика). Уровни концентраций
поллютантов сравнивали с аналогичными данными, полученными в пяти точках Европы:
Краков (Польша); Будапешт (Венгрия); Испра, Милан, Понзоне (Италия). Для мони-
торинга атмосферных выпадений вблизи нефтеперерабатывающего завода СЛОВНАФТ
собирали также образцы наземных мхов Р. sсhrеbегі и Н. splendепs. Элементное содер-
жание во мхах сравнивали со средними данными по Словакии и Норвегии.
Работа выполнена в Лаборатории нейтронной физики им. И. М. Франка ОИяИ и на
факультете математики, физики и информатики Университета им. Я. Коменского, Брати-
слава (Словакия).
Препринт Объединенного института ядерных исследований. Дубна, 2009

Meresova J. et al.

E18-2009-27

Air Pollution Studies in Slovakia Using Aerosol Filters and Biomonitoring Technique

Instrumental neutron activation analysis (INAA) and atomic absorption spectrometry (AAS) were employed in order to evaluate the concentrations up to 36 chemical elements (heavy metals, rare earths, and actinides) in the atmospheric aerosols. Two sampling sites in Bratislava were examined. The first site Líščie údolie is quite pristine location with a low traffic concentration. The second sampling site is close to the crude oil processing plant SLOVNAFT. The influence of the steel industry in Vel'ká Ida and thermal power plant in Prievidza was investigated. Most heavily contaminated sampling site in the vicinity of surface coal mine Tušimice in Czech Republic was also included in this study. The levels of pollutant concentrations were compared to those in atmosphere of other five European sites: Cracow (Poland); Budapest (Hungary); Ispra, Milan, Ponzone (Italy). The terrestrial mosses $P$. schreberi and H. splendens were collected in the environs of the oil plant SLOVNAFT to monitor heavy metal atmospheric deposition. The elemental concentrations in moss samples were compared to the Slovakian and Norwegian median values.

The investigation has been performed at the Frank Laboratory of Neutron Physics, JINR and at the Faculty of Mathematics, Physics and Informatics, Comenius University, Bratislava (Slovakia). 


\section{INTRODUCTION}

Elemental concentrations of airborne particulate matter can provide important information on the degree of atmospheric pollution and further evaluation of the potential health risk to the population. For this reasons it is necessary to know their chemical composition and physical characteristics in order to understand their behavior and impact.

Between many pollutants heavy metals are the most toxic component for all living organisms. Some heavy metals play an important role in the nutrition of plants, animals and humans $(\mathrm{Mn}, \mathrm{V}, \mathrm{Cr}, \mathrm{Ni}, \mathrm{Cu}, \mathrm{Zn})$, but if they occur in excess, they may produce certain toxic effects. Such elements as $\mathrm{Cd}, \mathrm{Hg}, \mathrm{Pb}$ are toxic even in a very low contents. Heavy metals are present in the atmosphere in organic and also in inorganic compounds, in the form of dust and aerosols. They can be transported to large distances from the source and where they fall out they produce a very negative impact on the environment.

Heavy metals are released into the environment from a great number of sources. Combustion of fossil fuels is the main anthropogenic source of $\mathrm{Ni}, \mathrm{V}$, $\mathrm{Cd}$, As, and $\mathrm{Zn}$ (Pacyna, 1986). Pb, Sb, Br, Cr, and V are elements associated with automotive exhaust products and domestic heating. Non-ferrous smelters are the sources of $\mathrm{Cu}, \mathrm{Zn}, \mathrm{Cd}$, and $\mathrm{Pb}$. The largest source of airborne $\mathrm{Cd}$ in the environment is the burning of fossil fuels such as coal or oil, and incineration of municipal waste materials. Cd may also be emitted into the air from zinc, lead, or copper smelters. The current anthropogenic metal emissions are up to several orders of magnitude higher than their natural contents (Chmielewska et al., 2003). Resuspended soil particles, volcanic aerosols and forest fires contribute to natural emissions of trace elements such as $\mathrm{Cr}, \mathrm{Mn}, \mathrm{V}, \mathrm{Cu}, \mathrm{Mo}, \mathrm{Ni}$, and $\mathrm{Zn}$ (Pacyna, 1998). It has to be noted, that Th and $U$ are elements relatively abundant in Earth crust, and hence their concentrations in oil are significant. The data on elemental concentration in the Slovakian atmospheric aerosol particles are very scared and limited for a few elements (Burda et al., 2006).

More than three decades mosses are used as biomonitors. This technique is presently widely accepted as method to assess the atmospheric deposition of metals (Rühling, Steinnes, 1998; Smodis et al., 2004). In the Slovak Republic extensive studies in this direction have been done by Maňkovská from the year 
1991 (Maňkovská, 1997). Mosses have only a rudimentary root system and readily take up elements from the atmosphere. Results from moss surveys are regularly published (each five years) in the Atlas of Heavy Metal Atmospheric Deposition in Europe by the UNECE ICP Vegetation (European Atlas, 2003, 2008).

Instrumental neutron activation analysis (INAA) and atomic absorption spectrometry (AAS) are two complementary analytical techniques used to determine the contents of trace elements in airborne particulate matter in air filters and in moss samples. Currently INAA is considered as the most suitable and appropriate analytical technique for multi-elemental analysis of aerosol samples (Dams, 1992; Frontasyeva, 2006). The main advantages of this method are high precision, high selectivity and sensitivity, small sample quantity needed, direct non-destructive method, etc.

\section{MATERIALS AND METHOD}

The main objective of this study was to determine the maximum possible number of elemental concentrations, including heavy metals, in the atmospheric aerosol particles at five sites with different anthropogenic impact. Two sampling sites are located in Bratislava: Líščie údolie and SLOVNAFT. The other two, Prievidza, and Vel'ká Ida, are in the polluted areas of Slovakia; the last one, Tušimice, is in the Czech Republic. In the vicinity of the refinery SLOVNAFT spatial and temporal trends in heavy metal deposition were also studied using the moss biomonitoring technique.

Description of Sampling Sites. Bratislava is a city with population of approximately 500, 000. The chemical industry, technical glasswork, building industry, incineration plant, and car industry are located in the larger city area. Neither a ferrous or non-ferrous smelter, nor a power plant is in the vicinity. The refinery and petrochemical company SLOVNAFT, one of the biggest in the Central Europe, allocates in the area of $5.2 \mathrm{~km}^{2}$ at the southeast border of the capital of SR Bratislava. Annually SLOVNAFT processes approximately 5 millions tones of crude oil supplied mainly from the Russian Federation. SLOVNAFT delivers to the market the complete range of refinery, petrochemical products and plastics.

The station Prievidza $\left(48^{\circ} 46^{\prime} \mathrm{N}, 18^{\circ} 37^{\prime} \mathrm{E}\right)$ is located in the town centre, close to 4-storey residential houses and buildings of similar height. Near the station, passes slight traffic. Close to the city Prievidza is the mine Nováky with annual coal production of 1900 thousands tons. Coal is predominantly burned (85\%) in thermal power plant Nováky with $518 \mathrm{MW}$ of power capacity. Also chemical industry is located in the town Nováky.

The station Vel'ká Ida $\left(48^{\circ} 35^{\prime} \mathrm{N}, 21^{\circ} 10^{\prime} \mathrm{E}\right)$ is located in the southeastern part of the Vel'ká Ida municipality, in a relatively open area. In the vicinity of the station are located family houses, gardens, railway stations and waste dumps of 
slag, which are not fully grassed. Close to the town of Vel'ká Ida is the largest in Slovakia ferrous metallurgy complex, U.S. Steel Košice.

The Czech sampling site Tušimice is located in the meteorological station $\left(50^{\circ} 22^{\prime} \mathrm{N} ; 13^{\circ} 20^{\prime} \mathrm{E}\right)$ of the Czech Hydrometeorological Institute in the open land with low building density. The area is affected by operation of the surface coal mines. In the year of 1998 the thermal power plant Tušimice-I was terminated. The power plant Tušimice-II has been working with power capacity of $4 \times 200 \mathrm{MW}$.

Aerosol and Moss Sampling. Sampling of atmospheric aerosol particles was performed during 2004-2006. At sites Líščie údolie and SLOVNAFT the nitrocellulose membrane filters PRAGOPOR (collection efficiency $\sim 100 \%$ ) were used. About $3000 \mathrm{~m}^{3}$ of air was pumped through each individual sample. At other sampling stations the glass-fiber filters MILLIPORE were used and the volume of air sampled was about $55 \mathrm{~m}^{3}$. Therefore, the uncertainties of the results for these particular sites are quite high.

The terrestrial moss samples of Pleurozium schreberi and Hylocomium splendens were collected in the environs of the oil plant SLOVNAFT to monitor atmospheric deposition of pollutants. Sampling was carried out according to guidelines of the UNECE ICP Vegetation survey in 2000 and 2006 (Harmens et al., 2008, Schröder et al., 2008).

Measurement of Elemental Concentrations. Instrumental Neutron Activation Analysis (INAA) at the reactor IBR-2 at the Joint Institute for Nuclear Research, Dubna, was used for determination of elemental concentration in aerosol filters and moss samples. The irradiation facility is described elsewhere (Frontasyeva et al., 2006). The content of some environmentally meaningful elements such as $\mathrm{Ni}, \mathrm{Cu}, \mathrm{Zn}, \mathrm{Cd}$, and $\mathrm{Pb}$, not detectable by INAA, were determined using AAS at the Institute of Geology, Comenius University (Medved' et al., 2003). The concentrations of $\mathrm{Hg}$ were measured by the Trace Mercury Analyzer TMA-254.

\section{RESULTS ON ELEMENTAL CONCENTRATIONS IN ATMOSPHERIC AEROSOL}

Atmospheric concentration levels for four Slovakian and one Czech sampling sites are presented in Table 1. For most of elements the results were obtained for the first time. Our results may be considered as the representative and unique data on elemental concentrations in the atmospheric aerosol for the investigated locations.

Crustal Enrichment Factors. The concept of enrichment factors (EF) was introduced by Rahn (1971) to detect contributions of non-crustal sources on observed concentrations of elements. EF compares the ratio of the concentration of element $c(x)$ in question to that of a selected reference element $c(\mathrm{Al})$ in a 
sample, and the corresponding ratio in the average composition of the Earth's crust

$$
\mathrm{EF}=\frac{\left(\frac{(c(x)}{c(\mathrm{Al})}\right)_{\text {sample }}}{\left(\frac{c(x)}{c(\mathrm{Al})}\right)_{\text {crust }}}
$$

Aluminum ( $\mathrm{Al}$ ) was used as a soil (crust) reference element. Also $\mathrm{Ti}$ is sometimes used as reference element. The average elemental concentrations in humus horizon of soil for Slovakia are used in the EF calculations (Čurlík et al., 1999).

Enrichment indicates natural volatilization, marine sources and anthropogenic activities. Rahn (1976) suggested classification criteria of EF: if $\mathrm{EF}<7$, then air particulate is of crustal origin and if EF $>10$, then it is of the anthropogenic one. Unfortunately, neither Al nor Ti were measured in aerosol samples, except sites Liščie údolie and SLOVNAFT in Bratislava. For these were calculated EFs considering $\mathrm{Al}$ as reference element. Results are presented in Table 1. The values of $\mathrm{EF}$ for site Líščie údolie indicate the soil origin of $\mathrm{Mn}, \mathrm{Fe}, \mathrm{Cs}$, Th, and $\mathrm{U}$. Following Rahn's criteria, one can conclude that $\mathrm{Cu}, \mathrm{Zn}, \mathrm{As}, \mathrm{Se}, \mathrm{Cd}, \mathrm{Hg}$, and $\mathrm{Pb}$ are of the anthropogenic origin. For SLOVNAFT site high pollution by $\mathrm{Cu}, \mathrm{Cd}$, and $\mathrm{Pb}$ is observed.

Temporal and Spatial Variation of Atmospheric Concentrations. Figure 1 shows a decreasing trend of air pollution by heavy metals in Bratislava since

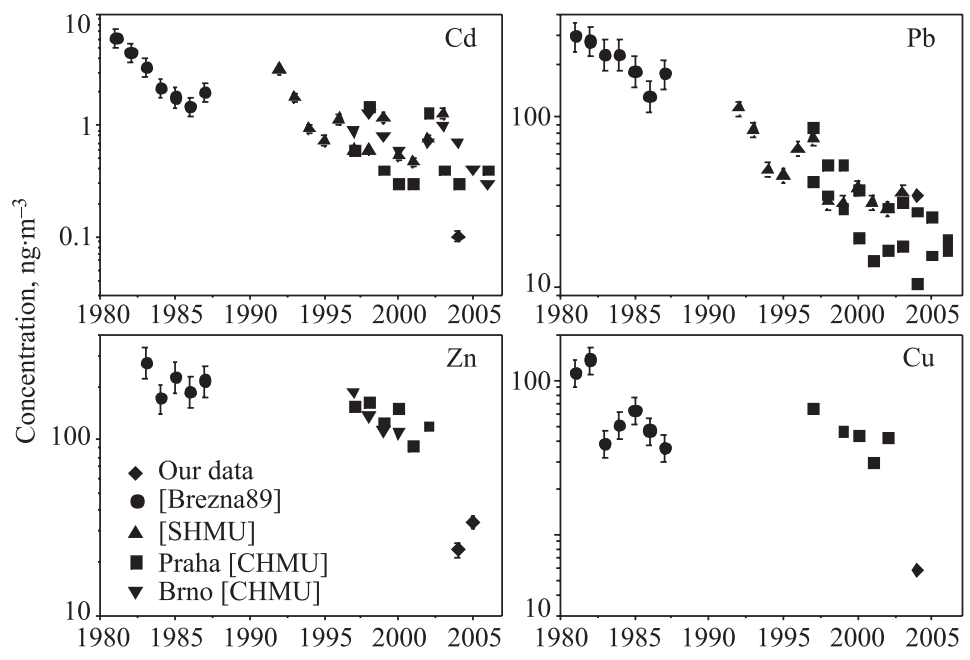

Fig. 1. Temporal variation of atmospheric concentrations of $\mathrm{Cd}, \mathrm{Pb}, \mathrm{Zn}$, and $\mathrm{Cu}$ in Bratislava, circle - (Brežná et al., 1989), triangle - (SHMU), diamond - our data. For comparison are shown also elemental concentrations in Prague (square) and Brno (reverse triangle) (CHMU) 
Table 1. Atmospheric concentrations - AC $\left(\mathbf{n g} \cdot \mathbf{m}^{-3}\right)$ and enrichment factors - EF for 4 sampling sites in Slovakia and one in the Czech Republic

\begin{tabular}{|c|c|c|c|c|c|c|c|}
\hline Location & \multicolumn{2}{|c|}{ Liščie údolie } & \multicolumn{2}{|c|}{ SLOVNAFT } & Vel'ká Ida & Prievidza & Tušimice \\
\hline & $\mathrm{AC}$ & $\overline{E F}$ & $\mathrm{AC}$ & $\mathrm{EF}$ & \multicolumn{3}{|c|}{$\mathrm{AC}$} \\
\hline $\mathbf{N a}$ & 104 & 3.8 & & & & & \\
\hline$\overline{\mathrm{Al}}$ & 189 & 1 & 184 & 1 & & & \\
\hline Cl & 49 & & & & & & \\
\hline $\mathbf{K}$ & 195 & 3.6 & & & & & \\
\hline $\mathbf{C a}$ & 179 & 9.1 & & & & & \\
\hline$\overline{\text { Sc }}$ & 0.0320 & & & & & & 4.6 \\
\hline Ti & 7.8 & & & & & & \\
\hline $\mathbf{V}$ & 0.83 & & & & & & \\
\hline $\mathrm{Cr}$ & 1.1 & 4.2 & 2.8 & 11 & 1.1 & 1.2 & 150 \\
\hline Mn & 4.9 & 2.2 & & & & & 13 \\
\hline $\mathbf{F e}$ & 252 & 3.0 & & & 643 & 435 & \\
\hline Co & & & 0.3 & & 0.42 & 0.19 & 1.37 \\
\hline $\mathbf{N i}$ & 0.45 & 5.6 & 5.1 & 65 & $1.6^{*}$ & $1.0^{*}$ & 4.4 \\
\hline $\mathbf{C u}$ & 8.0 & 150 & 41 & 770 & 18 & 21 & 9.0 \\
\hline $\mathbf{Z n}$ & 28 & 150 & & & 1294 & 1515 & 26122 \\
\hline$\overline{\text { Ga }}$ & 0.02 & 0.52 & & & & & \\
\hline As & 0.3 & 13 & & & $1.7^{*}$ & $7.9^{*}$ & 1.5 \\
\hline Se & 0.42 & 400 & & & & 0.18 & \\
\hline $\mathbf{S r}$ & & & 3.1 & & & & 480 \\
\hline $\mathbf{B r}$ & 3.5 & & & & & & 2.5 \\
\hline$\overline{C d}$ & 0.11 & 120 & 2.2 & 2350 & $1.1^{*}$ & $0.4^{*}$ & 7.1 \\
\hline In & 0.001 & & & & 0.045 & 0.042 & \\
\hline $\mathbf{S b}$ & 1.0 & 460 & & & 1.37 & 5.5 & 2.4 \\
\hline I & 0.66 & & & & & 0.44 & \\
\hline Cs & 0.045 & 2.8 & & & 0.028 & 0.032 & $\overline{1.9}$ \\
\hline Sm & 0.012 & & & & 0.84 & 0.89 & 0.5 \\
\hline $\mathbf{E u}$ & & & & & 1.9 & 0.84 & \\
\hline Dy & 0.01 & & & & & & \\
\hline Tm & 0.1 & & & & & 0.016 & \\
\hline$\overline{\text { Hf }}$ & & & & & 0.018 & 0.022 & \\
\hline Ta & & & & & 0.13 & 0.08 & \\
\hline $\mathbf{W}$ & 0.22 & & & & & & \\
\hline$\overline{\mathrm{Hg}}$ & 0.064 & 250 & & & $<4.2$ & $<4.2$ & \\
\hline$\overline{\mathbf{P b}}$ & 22 & 350 & 42 & 670 & 90 & 29 & 45 \\
\hline Th & 0.042 & 1.4 & & & & & 1.4 \\
\hline $\mathbf{U}$ & 0.012 & 1.2 & & & & & 0.2 \\
\hline
\end{tabular}

${ }^{*}$ Data are taken from Burda et al. (2006). 

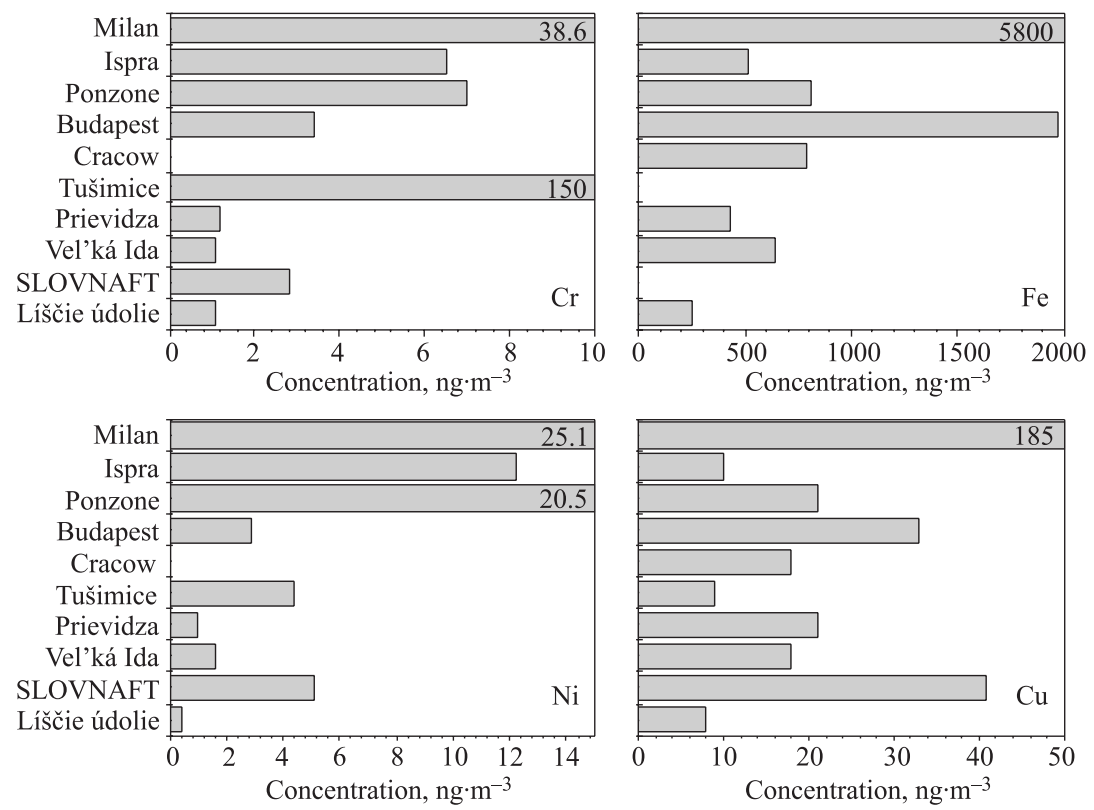

Fig. 2. Atmospheric concentrations of $\mathrm{Cr}, \mathrm{Fe}, \mathrm{Ni}$, and $\mathrm{Cu}\left(\mathrm{ng} \cdot \mathrm{m}^{-3}\right)$ for 10 European sampling sites. Slovakia: Bratislava (SLOVNAFT and Liščie údolie), Prievidza, Vel'ká Ida; Czech Rep.: Tušimice and Italy: Milan (Gallorini et al., 1999), Ispra (Rizzio et al., 1999), Ponzone (Rizzio et al., 2001); Hungary: Budapest (Salma et al., 2002); Poland: Cracow (Wróbel et al., 2000)

the year 1981. The emissions of $\mathrm{Pb}$ have decreased, reflecting the shift from leaded to unleaded gasoline. The further explanation of this decreasing trend is the declination of industry in Slovak Republic after the year 1989, since the fuel burning processes in thermal power plants and industry plants are a major source of atmospheric pollution with heavy metals. The emissions of pollutants were reduced also via utilization of more rigid requirements in the environmental legislation and employment of new more effective filtration techniques.

For several environmentally meaningful elements $(\mathrm{Cr}, \mathrm{Fe}, \mathrm{Ni}, \mathrm{Cu}, \mathrm{Zn}, \mathrm{As}$, $\mathrm{Cd}, \mathrm{Pb}$ ) our results compared to relevant data from some European cities as can be seen in Figs. 2 and 3. The city of Milan is the industrial centre of the northern Italy, thus concentrations of almost all elements are obviously the highest in relevant aerosols. Ponzone is a small town where the major part of wool industries is settled, and Ispra is a residential settlement in the northern Italy. The main objective of the Cracow study was to determine the contribution of traffic to the particulate air pollution, and to characterize transport of aerosols in urban area that are close $(5 \mathrm{~m})$ to the main road. Also, the location of Szena 

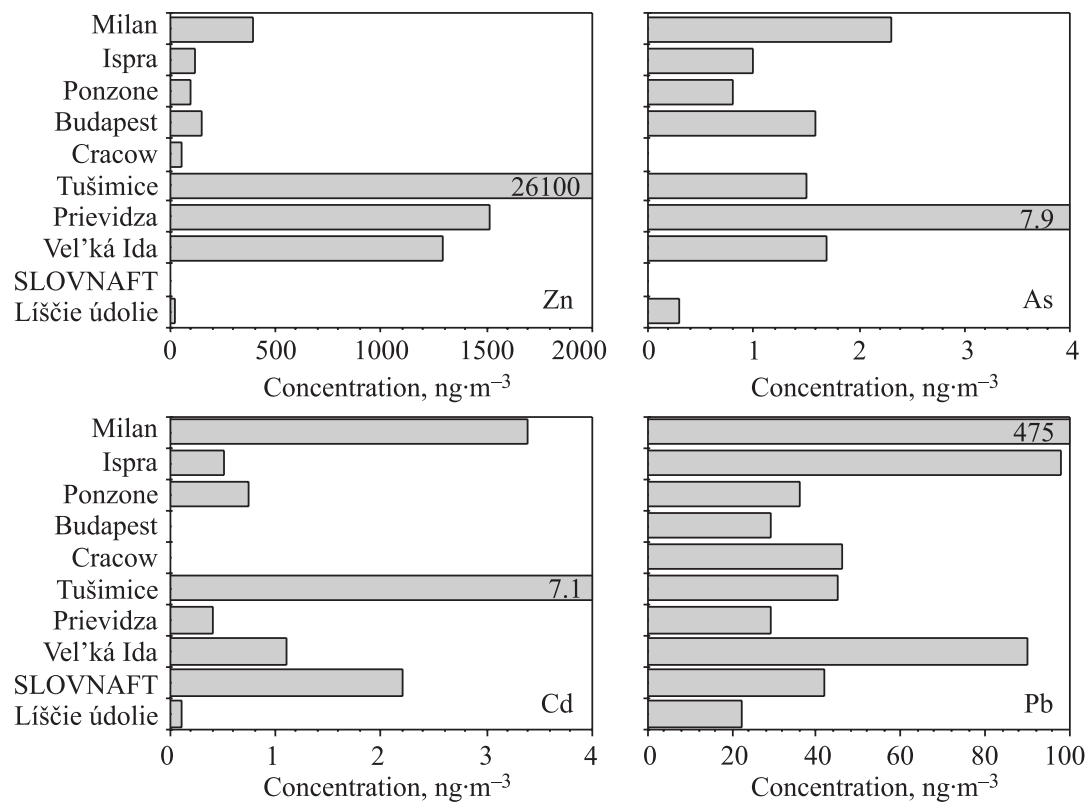

Fig. 3. Atmospheric concentrations of $\mathrm{Zn}$, $\mathrm{As}, \mathrm{Cd}$, and $\mathrm{Pb}\left(\mathrm{ng} \cdot \mathrm{m}^{-3}\right)$ for 10 European sampling sites

Square in Budapest has a more closed downtown character and is affected by heavy traffic.

The concentrations of almost all elements are lower in Bratislava - Líščie údolie compared to the other localities, or comparable to the Italian sites of Ponzone and Ispra, which are typically low pollution areas. The low-level atmospheric pollution in Bratislava may be caused by a small number of pollution sources, and in particular by typical for this location the high number of windy days per year. This statement is supported by the negative correlation between the wind velocity and the elemental concentrations in our samples (Merešová et al., 2008). Moreover, in this paper the seasonal variations were discussed.

On the contrary, the SLOVNAFT site is affected by the oil processing refinery. The concentrations of elements typical for oil combustion like $\mathrm{Ni}$ and $\mathrm{Cd}$ are elevated, and $\mathrm{Cr}, \mathrm{Pb}$, and $\mathrm{Cu}$ reach high levels as well. Unfortunately, we have no results for $\mathrm{V}$, since the increased concentrations would also be expected.

The comparison of two sampling sites, Tušimice and Prievidza, is very interesting since both are affected by the mining and combustion of coal in the power plants. Tušimice is the most heavily polluted area in this study. Mining operations in the surface coal mines increase atmospheric concentrations of $\mathrm{Cr}, \mathrm{Zn}$, and $\mathrm{Cd}$. The concentration of $\mathrm{U}$ is one order of magnitude higher in Tušimice than 
in Bratislava. Coal mines near Prievidza are underground, therefore the concentrations of pollutants are lower there in comparison to the Tušimice. Particularly high concentration was measured for As. Its value exceeds the maximum permissible level for urban air. The lignite mined in this area is very rich in As, and its typical concentrations range from 519 to $863 \mathrm{mg} \cdot \mathrm{g}^{-1}$ (Keegan et al., 2002). In dataset from Vel'ká Ida we observe high concentrations of $\mathrm{Fe}, \mathrm{Pb}$, and $\mathrm{Zn}$, the elements emitted into the atmosphere during the smelting processes. Thus the impact of nearby U.S. Steel is obvious.

\section{RESULTS ON BIOMONITORING SURVEY}

The concentrations of 41 elements were determined in moss samples collected in 2000 and 2006 from several locations in vicinity of SLOVNAFT refinery. The spatial and temporal trends in elemental deposition were studied. The results include heavy metals, non-ferrous metals, halogens, and rare-earths, as well. Five locations with different distance from the refinery were investigated in 2000 , and three more sites in 2006.

Contamination Factor. In order to evaluate the level of pollution of the refinery SLOVNAFT the concentrations of several elements were compared with the representative background concentrations. Usually the median concentrations from the Norwegian locations are used as reference background values corresponding to pristine undisturbed environment (Steinnes et al., 2001). In Fig. 4 the contamination factors for each particular site (labeled by its distance from refinery in $\mathrm{km}$ ) are presented. Contamination factor is calculated as ratio of Slovak to Norwegian concentrations. For most of elements at all sampling sites the contamination factors are higher than one. The concentrations of some elements measured in Slovak mosses (Al, V, Cr, Fe, Co, Sr, Cd, Sb, U) are 10 times higher in comparison to the background values.

In the UNECE ICP Vegetation survey (UNECE ICP 2003) Slovakia is classified as a rather polluted European country. The main sources of heavy metal emissions are the industrial centers of the Upper Nitra Basin, Žiar Basin, and Váh Valley in the west, and Central Spiš, towards the east (UNECE ICP 2003). The previous moss biomonitoring study of 86 Slovak sites (Maňkovská et al., 2003; Florek, Maňkovská et al., 2007) showed areas known by the previous or present mining and processing of non-ferrous metals (Volovské vrchy in Slovenské Rudohorie, Kremnické, and Štiavnické vrchy). In north-northwest border areas of Slovakia the elevated concentration of $\mathrm{Hg}$ was determined. Most probably, it reflects the long-range transport form the Katowice-Ostrava region also known as the 2nd Black Triangle. The huge amount of coal is mined here and, accompanied by metallurgical, chemical industry, and mechanical engineering, significantly influence the environment. 


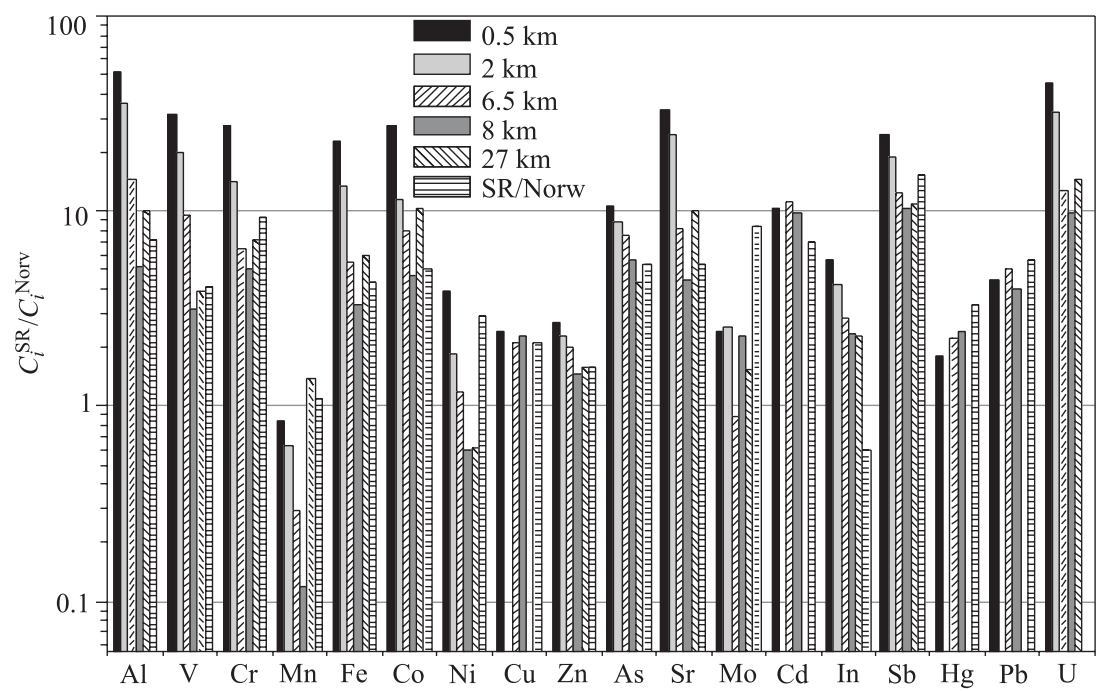

Fig. 4. Contamination factors of some elements in moss samples from vicinity of the refinery SLOVNAFT in 2000. The Norwegian concentrations are taken as reference background values. The sampling sites are labeled by its distance from the refinery $(\mathrm{km})$. The last bars correspond to concentration ratio of Slovak median and background (SR/Norw)

The course of prevailing winds in Bratislava mostly determines the impact of SLOVNAFT refinery. The east-southeast areas are the most affected by operation of the refinery. In remote sites (Záhorie, Jabloňové, Rusovce and Čúnovo) the contamination factor is usually markedly lower as the ratio of the medians (Fig. 4.) indicating lower pollution. Concentrations of $\mathrm{Al}, \mathrm{Cr}, \mathrm{Fe}, \mathrm{As}, \mathrm{Sb}$, and $\mathrm{Th}$ in moss samples collected at these sites are close to the Slovak median values. Only values of $\mathrm{V}, \mathrm{Co}$, and $\mathrm{U}$ demonstrate distinct increase.

Low concentrations of specific group of heavy metals $(\mathrm{Cu}, \mathrm{In}, \mathrm{Cd}$, and $\mathrm{Sb}$ ) in the close vicinity of refinery are naturally lower as the particulates including these elements are easily transported with wind outside the territory of the plant. Their deposition at the territory of the plant is comparable to the Slovak median values. Moreover, pollution with the toxic elements, like $\mathrm{Hg}$ and $\mathrm{Pb}$, is lower than the Slovak median.

Total Annual Deposition. Since 1990 the moss biomonitoring method is widely used in Europe for the deposition evaluation purposes. Suchara and Sucharová (1999) proposed the method for total annual deposition $D\left(\mathrm{mg} \cdot \mathrm{m}^{-2} \cdot \mathrm{y}^{-1}\right)$ calculation. Table 2 presents the assessment annual deposition $D$ for the sampling site Rusovce. Also minimal and maximal depositions determined for 86 Slovak 
Table 2. Assessment of total annual depositions $D\left(\mathrm{mg} \cdot \mathrm{m}^{2} \cdot \mathbf{y}^{-1}\right)$ for several elements at the Rusovce site and minimal and maximal depositions in Slovakia (Florek and Maňkovská, 2007)

\begin{tabular}{|c|c|c|c|c|c|c|c|}
\hline & Rusovce & \multicolumn{2}{|c|}{ Slovakia } & & Rusovce & \multicolumn{2}{c|}{ Slovakia } \\
\hline Element & $D$ & $D_{\min }$ & $D_{\max }$ & Element & $D$ & $D_{\min }$ & $D_{\max }$ \\
\hline $\mathbf{A l}$ & 937 & 140 & 3200 & $\mathbf{N i}$ & 0,33 & 0,18 & 3,3 \\
\hline $\mathbf{A s}$ & 0,37 & 0,12 & 800 & $\mathbf{P b}$ & 3,24 & 1,2 & 14 \\
\hline $\mathbf{C d}$ & 0,21 & 0,02 & 0,3 & $\mathbf{S}$ & 1280 & 500 & 1400 \\
\hline $\mathbf{C o}$ & 0,35 & 0,08 & 2,1 & $\mathbf{V}$ & 3,37 & 0,45 & 7,8 \\
\hline $\mathbf{C r}$ & 0,84 & 0,2 & 7,9 & $\mathbf{T h}$ & 0,13 & 0,03 & 0,9 \\
\hline $\mathbf{C u}$ & 2,9 & 1,3 & 12 & $\mathbf{U}$ & 0,33 & 0,005 & 0,1 \\
\hline $\mathbf{F e}$ & 426 & 92 & 2900 & $\mathbf{Z n}$ & 13,7 & 4 & 31 \\
\hline
\end{tabular}

sites in the previous study (Florek and Maňkovská, 2007) are given in Table 2. The elemental depositions at the Rusovce site are within the range of the Slovak values, except the $\mathrm{U}$, where the deposition in Rusovce is three times higher than the maximal deposition of $U$ in Slovakia.

Comparison of Pollution in 2000 and 2006. The same five sampling sites were studied and three more sites were included to the investigation in 2006. The new sites are more distant from the refinery. Figure 5 shows relative concentrations $\left(C_{i}^{2006} / C_{i}^{2000}\right)$ for one neighboring site $(\sim 0.5 \mathrm{~km})$ and Rusovce site $(\sim 6.5 \mathrm{~km})$.

The ratio for most of elements is less than 1, indicating the decline of pollution. The concentrations decreased for approximately $40 \%$, except for Sc, $\mathrm{Ni}$, Se and the lanthanide group ( $\mathrm{La}, \mathrm{Ce}, \mathrm{Sm}, \mathrm{Tb}$ ) where the double concentrations

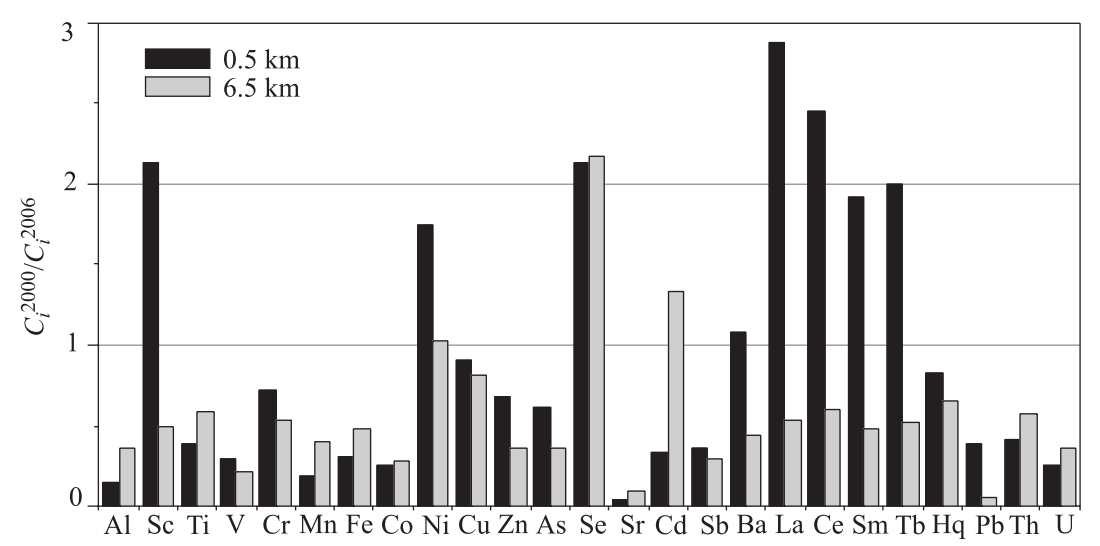

Fig. 5. Comparison of pollution in 2000 and 2006 in vicinity of the oil refinery SLOVNAFT based on moss biomonitoring method 
in 2006 in the close vicinity of the refinery were observed. This may be a result of different origin of oil processed in the refinery. The concentrations of lanthanides depend strongly on the oilfields location. There is a distinct variance between the oil from the Russian Federation and from the Middle East.

\section{CONCLUSIONS}

Data on atmospheric concentrations of a large set of elements including heavy metals, halogens, rare earths, uranium and thorium in particulate matter were obtained by INAA and AAS for the first time. Four Slovakian and one Czech sampling sites were investigated in this study. The conclusions are summarized as follows:

1. Decreasing trend of air pollution with heavy metals $(\mathrm{Cd}, \mathrm{Pb}, \mathrm{Zn}$, and $\mathrm{Cu})$ in Bratislava since 1981 was established.

2. Atmospheric concentrations of elements typical for oil combustion such as $\mathrm{Ni}$ and $\mathrm{Cd}$ are elevated in close vicinity of the refinery SLOVNAFT. Concentrations of $\mathrm{Cr}, \mathrm{Pb}$, and $\mathrm{Cu}$ are also increased. It is clear consequence of oil processing.

3. Crustal enrichment factors calculated for $\mathrm{Cu}, \mathrm{Zn}, \mathrm{As}, \mathrm{Se}, \mathrm{Cd}, \mathrm{Hg}$, and $\mathrm{Pb}$ at sites in Líšcie údolie and SLOVNAFT are classified as anthropogenic.

4. High concentration of As measured in Prievidza exceeds maximum permissible level and it corresponds to a very high content of As in lignite mined in this area.

5. Impact of nearby U.S. Steel in Vel'ká Ida is obvious for $\mathrm{Fe}, \mathrm{Pb}$, and $\mathrm{Zn}$ elevated concentrations.

6. Significantly increased airborne pollution $(\mathrm{Cr}, \mathrm{Zn}, \mathrm{Cd}$, and $\mathrm{U})$ was observed in the area of Tušimice affected by the operation of surface mine and combustion of coal in the thermal power plant Tušimice-II.

The following conclusions can be drawn based on the results of moss biomonitoring in the vicinity of SLOVANFT refinery.

1. Significant excess of pollutants in the close vicinity of refinery was observed. Concentrations of some elements (Al, V, Cr, Fe, Co, As, Sr, Cd, In, $\mathrm{Sb}, \mathrm{Sc}, \mathrm{Cs}$, Th, and U) in moss samples is 10 times higher in comparison to the Norwegian background values. Concentrations of $\mathrm{Al}, \mathrm{V}, \mathrm{Cr}, \mathrm{Fe}, \mathrm{Co}, \mathrm{Sr}, \mathrm{Sc}, \mathrm{Th}$, and $U$ are higher than the Slovak median.

2. Low concentrations of some heavy metals $(\mathrm{Cu}, \mathrm{In}, \mathrm{Cd}$, and $\mathrm{Sb})$ comparable to the Slovak medians were determined in samples from the closest to plant site.

3. Comparison of the results from 2000 and 2006 indicates $40 \%$ decrease of pollution for most of the elements.

4. For the Rusovce site total annual depositions of several elements were estimated according to concentrations of relevant elements in the moss samples. 
Except for $\mathrm{U}$, depositions of all elements are within the range of typical elemental depositions in Slovakia.

Acknowledgements. The authors acknowledge financials support by the Scientific grant agency of Ministry of education SR and SAV (VEGA project number 1/3046/06) and ESF project number JPD 3BA-2005/1-034) This work was supported by the grant of the Plenipotentiary of the Slovak Republic at the Joint Institute for Nuclear Research, Dubna. Authors are indebted to the Czech Hydrometeorological Institute for providing the aerosol filter samples from Tušimice station.

\section{REFERENCES}

1. Burda C. et al. 2006: Air Pollution in Slovak Republic 2006, SHMI Report.

2. Brežná M., Závodský D. 1989: Heavy metals in atmospheric aerosols in the region of Slovakia. Air Protection, 6: 144-148 (in Slovak).

3. Čurlík J., Šefč́k P. 1999: Geochemical atlas of the Slovak Republic. Soil. Ministry of Environment of Slovak Republic.

4. Chmielewska E., Spiegel H. 2003: Some control of an amplified heavy metal distribution at emission sites of Danube lowland refineries. Environment Protection Engineering, 29: 23-32.

5. Dams R. 1992: Nuclear activation techniques for the determination of trace elements in atmospheric aerosols, particulates and sludge samples. Pure and Applied Chemistry, 64: 991.

6. European Atlas. 2003: Heavy Metals in European Mosses: 2000/2001 Survey, UNECE ICP Vegetation / Eds. A. Buse, D. Norris, H. Harmens, P. Buker, T. Ashenden and G. Mills. Centre for Ecology \& Hydrology, University of Wales Bangor, UK (2008), Spatial and temporal trends in heavy metal accumulation in mosses in Europe (19902005), UNECE ICP Vegetation. Editors: H. Harmens, D. Norris and participants of the moss survey. Ibdd http://icpvegetation.ceh.ac.uk

7. Florek M., Maňkovská B., Oszlányi J., Frontasyeva M. V., Ermakova E. E., Pavlov S. S. 2007: The Slovak Heavy Metals Survey by Means the Bryophyte Technique. Ekológia (Bratislava), 1: 99-114,

8. Frontasyeva M. V. 2006: Neutron activation analysis at the IBR-2 reactor in Dubna for life sciences. Ecological Chemistry and Engineering, 13: 1-9.

9. Gallorini M., Rizzio E., Birattari C., Bonardi M., Croppi F. 1999: Content of trace elements in the respirable fractions of the air particulate of urban and rural areas monitored by neutron activation analysis. Biological Trace Element Research, 71, 209-222.

10. Goldhaber M., Irwin E.R., Atkins B. et al. 2000: Environmental impact of elevated arsenic in Southern Appalachian Basin coals. In: Centeno J. A., Collery G., Vernet R. B., Finkelman H., Gibb J.C., Etienne J.C. (Eds.), Metal Ions in Biology and Medicine. John Libbey Eurotext, Paris, 38-40. 
11. Harmens H., Norris A.D., Koerber G.R., Buse A., Steinnes E., Rühling A. 2008: Temporal trends (1990-2000) in the concentration of cadmium, lead and mercury in mosses across Europe. Environmental Pollution 151: 368-376.

12. Keegan T., Bing Hong, Thornton I., Farago M., Jakubiš P., Jakubiš M., Pesch B., Ranft U., Nieuwenhuijsen M. J. and the EXPASCAN Study Group, 2002: Assessment of environmental arsenic levels in Prievidza district. Journal of Exposure Analysis and Environmental Epidemiology, 12: 179-185.

13. Maňkovská B., Florek M. et al. 2003: Atmospheric deposition of heavy metals in Slovakia studied by the moss biomonitoring technique, neutron activation analysis and flame atomic absorption spectrometry. Ekologia, Bratislava, V.22, Supplement 1/2003, P. 157-162.

14. Maňkovská B. 1997: Deposition of heavy metals in Slovakia - Assessment on the basis of moss and humus analysis. Ekologia (Bratislava) 16, 433-442.

15. Medved' J., Streško V., Kubová J., Chmielewská E. 2003: Evaluation of Atomic Spectroscopy Methods for Determination of Some Heavy Metals in Soils, Soil Extracts, Plants and Biota. Chemical Papers, 57, 169-171.

16. Merešová J., Florek M., Holý K., Ješkovská M., Sýkora I., Frontasyeva M.V., Pavlov S. S. 2008: Evaluation of Elemental Content in Airborne Particulate Matter in Low-Level Atmosphere of Bratislava (Slovakia). Atmospheric Environment, 42: 8079-8085.

17. Pacyna J.M. 1986: In: J. O. Nriagu, C.I. Davison (Eds). Toxic metals in the atmosphere. New York: Wiley; 1-52.

18. Pacyna J.M. 1998: Source inventories for atmospheric trace metals. In: R. M. Harrison, R. E. van Grieken (Eds). Atmospheric particles. IUPAC Series Analytical and Physical Chemistry of Environmental Systems, V.5. Chichester, UK: Wiley; 385-423.

19. Rahn K.A. 1971: Sources of trace elements in aerosols - an approach to clean air. Ph.D. thesis, University of Michigan, Ann Arbor.

20. Rahn K.A. 1976: The chemical composition of the atmospheric aerosols. Technical report, Graduate School of Oceanography, University of Rhode Island.

21. Rizzio E., Giaveri G., Arginelli D., Gini L., Profumo A., Gallorini M. 1999: Trace elements total content and particle size distributions in the air particulate matter of a rural-residential area in north Italy investigated by instrumental neutron activation analysis. The Science of the Total Environment, 226: 47-56.

22. Rizzio E., Bergamaschi L., Valcuvia M. G., Profumo A., Gallorini M. 2001: Trace elements determination in lichens and in the airborne particulate matter for the evaluation of the atmospheric pollution in a region of northern Italy. Environment International, $26,543-549$.

23. Rühling A., Steinnes E. 1998: Atmospheric Heavy Metal Deposition in Europe 19951996. NORD Environment, NORD 1998:15.

24. Salma I., Maenhaut W., Záray G. 2002: Comparative study of elemental mass size distributions in urban atmospheric aerosol. Aerosol Science, 33: 339-356. 
25. Schröder W., Pesch R., Englert C., Harmens H., Suchara I., Zechmeister H. G. et al. 2008: Metal accumulation in mosses across national boundaries: Uncovering and ranking causes of spatial variation. Environmental Pollution 151: 377-388.

26. Smodis B. (IAEA), Pignata M. L. (Agrentina), Saiki M. (Brazil), Cortes Toro, E. (Chili), Ni B. (China), Markert B. (Germany), Nyarko B. J. B. (Ghana), Arunachalam J. (India), Garty J. (Israel), Voutchkov M. K. (Jamaica), Wolterbeek H.Th. (Netherlands), Steinnes E. (Norway), Freitas M.C.M. (Portugal), Lucaciu A. (Romania), Frontasyeva M. V. (Russian Federation). 2004: Validation and Application of Plants as Biomonitors of Trace Element Atmospheric Pollution - a Coordinated Effort in 14 Countries. Atmosph. Chem. V. 49. 3-13.

27. Steinnes E., Berg T., Sjobak T.E., Uggerud H., Vadset M. 2001: Atmospheric deposition of heavy metals in Norway (in Norwegian). Nation-wide survey 2000. Report 838/01, State Pollution Control Authority, Oslo, 28 p.

28. Suchara I., Sucharová J. 1999: Distribution of 36 element deposition rates in a historic mining and smelting area as determined through fine-scale biomonitoring techniques. Part I: Relative and absolute current atmospheric deposition levels detected by moss analysis. Water Air Soil Pollution, 153: 205-228.

29. Swaine D. J. 1994: Trace elements in coal and their dispersal during combustion. Fuel Process Technology, 39: 121-137.

30. Wróbel A., Rokita E., Maenhaut W. 2000: Transport of traffic-related aerosols in urban areas. Science of the Total Environment, 257: 199-211.

Received on February 18, 2009. 


\section{Корректор T. Е. Попеко}

Подписано в печать 07.05.2009.

Формат $60 \times 90 / 16$. Бумага офсетная. Печать офсетная.

Усл. печ. л. 1,18. Уч.-изд. л. 1,53 Тираж 280 экз. Заказ р 56595.

Издательский отдел Объединенного института ядерных исследований 141980, г. Дубна, Московская обл., ул. Жолио-Кюри, 6.

E-mail: publish@jinr.ru www.jinr.ru/publish/ 